\title{
Zhouia amylolytica gen. nov., sp. nov., a novel member of the family Flavobacteriaceae isolated from sediment of the South China Sea
}

Correspondence

Shuang-Jiang Liu liusj@sun.im.ac.cn

\author{
Zhi-Pei Liu, ${ }^{1}$ Bao-Jun Wang, ${ }_{1}$ Xin Dai, ${ }^{1}$ Xing-Yu Liu ${ }^{1,2}$ \\ and Shuang-Jiang Liu ${ }^{1}$
}

\begin{abstract}
${ }^{1}$ State Key Laboratory of Microbial Resources, Institute of Microbiology, Chinese Academy of Sciences, Zhongguancun, Haidian, Beijing 100080, People's Republic of China

${ }^{2}$ Graduate University of Chinese Academy of Sciences, Beijing 100049, People's Republic of China
\end{abstract}

\begin{abstract}
Three Gram-negative, non-spore-forming strains were isolated from sediment from the South China Sea, China, and their taxonomic positions were investigated using a polyphasic approach. Strains $\mathrm{HN}-171^{\top}, \mathrm{HN}-172$ and $\mathrm{HN}-181$ grew optimally at $30^{\circ} \mathrm{C}$, in the presence of $4 \cdot 5-5 \cdot 0 \mathrm{NaC}$ $\%(\mathrm{w} / \mathrm{v})$ and at $\mathrm{pH} 7 \cdot 2-7 \cdot 4$. They contained $\mathrm{MK}-6$ as the predominant respiratory quinone and contained iso- $\mathrm{C}_{15: 1} \mathrm{G}$, iso- $\mathrm{C}_{15: 0}$, summed feature 4 (iso- $\mathrm{C}_{15: 0} 2-\mathrm{OH}$ and/or $\mathrm{C}_{16: 1} \omega 7 \mathrm{c} / \mathrm{t}$ ) and $\mathrm{C}_{15: 0}$ as the major fatty acids. The DNA G+C content of strain $\mathrm{HN}-171^{\top}$ was $34.5 \mathrm{~mol} \%$. Phylogenetic analyses based on $16 \mathrm{~S}$ rRNA gene sequences demonstrated that strain $\mathrm{HN}-171^{\top}$, together with strains $\mathrm{HN}-172$ and $\mathrm{HN}-181$, formed a distinct evolutionary lineage within the family Flavobacteriaceae. The $16 \mathrm{~S}$ rRNA gene sequences of strains $\mathrm{HN}-171^{\top}, \mathrm{HN}-172$ and $\mathrm{HN}-181$ shared $99 \cdot 8-100 \%$ similarity with each other, and the sequence of strain $\mathrm{HN}-171^{\top}$ exhibited similarity values below $90 \cdot 2 \%$ with those of other members of the family Flavobacteriaceae. The closest relative of $\mathrm{HN}-171^{\top}$ was Coenonia anatina LMG $14382^{\top}(90 \cdot 2 \%)$. On the basis of their phenotypic and phylogenetic properties, the three isolates represent a novel genus and a novel species, for which the name Zhouia amylolytica gen. nov., sp. nov. is proposed. The type strain is $\mathrm{HN}-171^{\top}\left(=\right.$ CGMCC $\left.1.6114^{\top}=\mathrm{JCM} 14016^{\top}\right)$.
\end{abstract}

The family Flavobacteriaceae was proposed by Jooste (1985), and its description has since been subjected to repeated emendation (Bernardet et al., 1996, 2002). In addition to providing phylogenetic data, Bernardet et al. (2002) proposed minimal standards for separating the genera classified as belonging to the family Flavobacteriaceae: these standards included characteristics relating to pigmentation, gliding motility, the seawater requirement, growth at different temperatures, cellular fatty acid composition and DNA G + C content. Currently, the family Flavobacteriaceae contains 53 genera with validly published names. Twentytwo of these genera were established within the last 5 years, being based on bacterial isolates from marine environments: Aequorivita, Algibacter, Aquimarina, Arenibacter, Bizionia, Croceibacter, Dokdonia, Donghaeana, Gaetbulibacter, Gaetbulimicrobium, Gramella, Lacinutrix, Maribacter, Mesonia, Muricauda, Olleya, Robiginitalea, Stenothermobacter, Subsaxibacter, Subsaximicrobium, Ulvibacter and Winogradskyella (Bowman \& Nichols, 2002, 2005; Bruns et al., 2001; Cho \& Giovannoni, 2003, 2004; Ivanova et al., 2001; Jung

The GenBank/EMBL/DDBJ accession number for the 16S rRNA gene sequence of strain $\mathrm{HN}-171^{\top}$ is $\mathrm{DQ} 423479$. et al., 2005; Lau et al., 2006; Mancuso et al., 2005; Nedashkovskaya et al., 2003, 2004a, c, d, 2005a, b, c, d; Yoon et al., 2005, 2006a, b). The abundance of marine members of the Flavobacteriaceae suggests that the family potentially plays an important role in marine ecosystems and in biogeochemical cycles, in interaction with other marine organisms.

During a survey of the ecology and bacterial diversity of the South China Sea, many bacterial strains were isolated. Three of them, designated HN-171 ${ }^{\mathrm{T}}$, HN-172 and HN-181, form a deep branch within the family Flavobacteriaceae. In this communication, we describe the isolation of these three bacterial strains and our study using polyphasic taxonomy.

A sediment sample was collected from the South China Sea, China (sample site GPS position, $115^{\circ} 15 \cdot 90^{\prime}$ E $21^{\circ} 18 \cdot 65^{\prime}$ $\mathrm{N}$ ); the salinity of the overlying water was $3 \%$. Strains were isolated by spreading sample dilutions on marine agar 2216 (MA; Difco) and incubating the plates at $30{ }^{\circ} \mathrm{C}$. The cell morphology was examined by transmission electron microscopy (H600; Hitachi) and scanning electron microscopy (200; FEI Quanta). Gliding motility and flexirubin pigments were investigated according to the methods 
specified in the minimal standards for describing new taxa of the family Flavobacteriaceae (Bernardet et al., 2002). The Gram reaction was determined using cells grown on MA at $30{ }^{\circ} \mathrm{C}$ for $24 \mathrm{~h}$, according to the method described by Gerhardt et al. (1994). Endospore formation was determined after malachite-green staining (Dong \& Cai, 2001) of cells grown on MA. The $\mathrm{pH}$ range for growth was determined in marine broth 2216 (MB; Difco) that was adjusted to various $\mathrm{pH}$ values $(\mathrm{pH} 4 \cdot 4-9 \cdot 0$, in increments of $0 \cdot 2 \mathrm{pH}$ units) with $\mathrm{HCl}$ or $\mathrm{NaOH}$ prior to sterilization. Growth in the presence of various $\mathrm{NaCl}$ concentrations was investigated in $\mathrm{MB}$ : the final concentrations (i.e. including the original concentration in $\mathrm{MB}$ ) are given below. Growth at various temperatures $\left(4-45^{\circ} \mathrm{C}\right.$, in increments of $\left.3{ }^{\circ} \mathrm{C}\right)$ was measured on MA. Anaerobic growth was determined in MB in an anaerobic test tube filled with nitrogen gas. Catalase activity was assessed from the formation of bubbles after a $3 \% \mathrm{H}_{2} \mathrm{O}_{2}$ solution was dropped onto a fresh colony. Oxidase activity and the hydrolysis of casein, starch, gelatin and Tweens 20,40, 60 or 80 were determined as described by Dong \& Cai (2001) with artificial seawater. The ability of the three isolates to utilize a battery of 95 different carbon sources was tested using GN MicroPlates (Biolog) inoculated with cells suspended in sterile artificial seawater. The artificial seawater contained the following $\left(1^{-1}\right.$ distilled water): $23.6 \mathrm{~g} \mathrm{NaCl}, 0.64 \mathrm{~g} \mathrm{KCl}, 4.53 \mathrm{~g} \mathrm{MgCl}_{2} .6 \mathrm{H}_{2} \mathrm{O}$, $5.94 \mathrm{~g} \mathrm{MgSO}_{4} .7 \mathrm{H}_{2} \mathrm{O}$ and $1.3 \mathrm{~g} \mathrm{CaCl}_{2} \cdot 2 \mathrm{H}_{2} \mathrm{O}$ (Bruns et al., 2001). Cells for the analysis of cellular fatty acids were grown on MA for 2 days at $30^{\circ} \mathrm{C}$, and the cellular fatty acid composition was determined as described previously $(\mathrm{Hu}$ et al., 2004, and references therein). Biomass for the analysis of isoprenoid quinones was grown in $\mathrm{MB}$; the quinones were determined according to Collins (1985) and $\mathrm{Wu}$ et al. (1989). DNA G + C contents were determined by thermal denaturation (Marmur \& Doty, 1962) using the DNA of Escherichia coli DH5 $\alpha$ as a standard for calibration of the $T_{\mathrm{m}}$ value. The $16 \mathrm{~S}$ rRNA gene was amplified and sequenced as described previously (Zhang et al., 2003) and sequences were aligned using the CLUSTAL X program (Thompson et al., 1997). Phylogenetic trees were constructed using the neighbour-joining method (Saitou \& Nei, 1987) with the Kimura two-parameter model in TREECON w, version $1.3 \mathrm{~b}$ (Van de Peer \& De Wachter, 1994) and the maximumparsimony method (Fitch, 1971).

The morphological, physiological and biochemical characteristics of strain $\mathrm{HN}-171^{\mathrm{T}}$ are given in the species description. The differentiating features for the three isolates and phylogenetically related genera are listed in Table 1 . The almost-complete $16 \mathrm{~S}$ rRNA gene sequence (1478 nt) of strain $\mathrm{HN}-171^{\mathrm{T}}$ was determined. Phylogenetic trees based on $16 \mathrm{~S}$ rRNA gene sequences showed that strains $\mathrm{HN}-171^{\mathrm{T}}$, HN-172 and HN-182 form a distinct phylogenetic lineage within the family Flavobacteriaceae (Fig. 1); strain $\mathrm{HN}-171^{\mathrm{T}}$ exhibits the highest similarity to Coenonia anatina LMG $14382^{\mathrm{T}}(90 \cdot 2 \%)$.

The isoprenoid quinone of strains $\mathrm{HN}-171^{\mathrm{T}}, \mathrm{HN}-172$ and HN-181 was MK-6. All three strains contained branched,

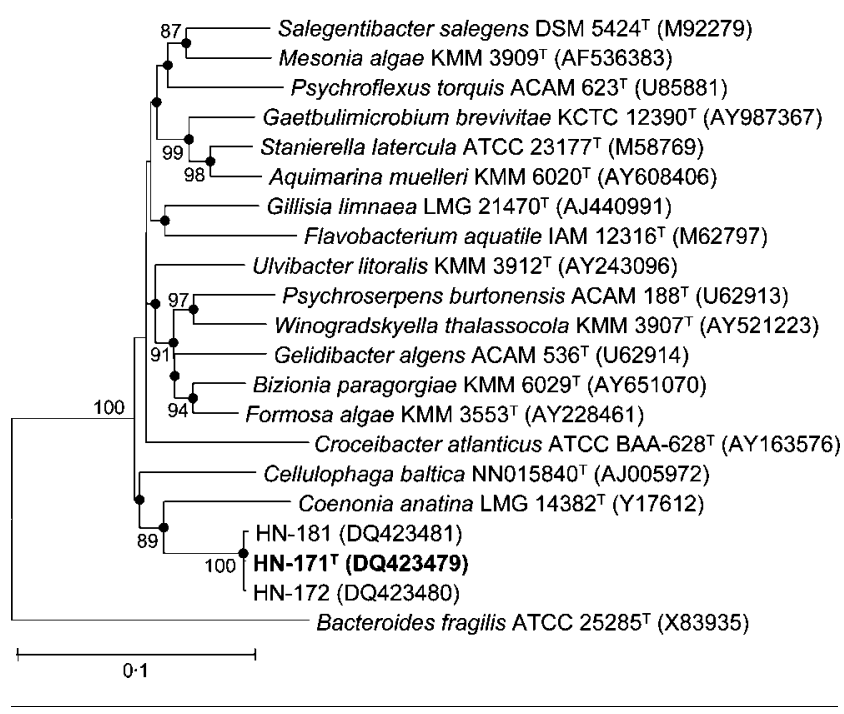

Fig. 1. Neighbour-joining tree, based on 16S rRNA gene sequences (1394 bp), showing the phylogenetic position of strain $\mathrm{HN}-171^{\top}$ and representatives of some related taxa. Bootstrap values (expressed as percentages of 1000 replications) $>50 \%$ are shown at branching points. Bacteroides fragilis ATCC $25285^{\top}$ was used as an outgroup. Filled circles indicate that the corresponding nodes were also recovered in the tree generated with the maximum-parsimony algorithm. Bar, $0 \cdot 1$ substitutions per nucleotide position.

hydroxyl, straight-chain and unsaturated fatty acids. The fatty acid profile of strain $\mathrm{HN}-171^{\mathrm{T}}(>1 \%$ of total fatty acids) comprised iso- $\mathrm{C}_{15: 1} \mathrm{G}(24 \cdot 2 \%)$, iso- $\mathrm{C}_{15: 0}(14 \cdot 9 \%)$, summed feature 4 (iso- $\mathrm{C}_{15: 0} 2-\mathrm{OH}$ and/or $\mathrm{C}_{16: 1} \omega 7 c / t$ ) $(10 \cdot 7 \%), \mathrm{C}_{15: 0}(9 \cdot 4 \%), \mathrm{C}_{16: 0}(4 \cdot 9 \%)$, iso- $\mathrm{C}_{15: 0} 3-\mathrm{OH}$ $(3 \cdot 9 \%), \mathrm{C}_{14: 0}(2 \cdot 5 \%), \mathrm{C}_{15: 0} 2-\mathrm{OH}(1 \cdot 4 \%)$, iso- $\mathrm{C}_{13: 0} 3-\mathrm{OH}$ $(1 \cdot 4 \%)$ and anteiso- $\mathrm{C}_{15: 0}(1 \cdot 1 \%)$. The DNA G $+\mathrm{C}$ content of strain $\mathrm{HN}-171^{\mathrm{T}}$ was $34 \cdot 5 \mathrm{~mol} \%\left(T_{\mathrm{m}}\right)$.

The three isolates differed from their close phylogenetic neighbours in the family Flavobacteriaceae in terms of a number of phenotypic and chemotaxonomic properties (Table 1). In particular, the novel isolates contained the characteristic fatty acid summed feature 4 . On the basis of the phenotypic and phylogenetic data, we propose the creation of a novel genus and species in the family Flavobacteriaceae, Zhouia amylolytica gen. nov., sp. nov., to accommodate the three strains $\mathrm{HN}-171^{\mathrm{T}}, \mathrm{HN}-172$ and HN-181.

\section{Description of Zhouia gen. nov.}

Zhouia (Zhou'i.a. N.L. fem. n. Zhouia named after Professor Pei-Jin Zhou, a pioneer of environmental microbiology in China).

Cells are Gram-negative, non-motile, non-spore-forming rods. Strictly aerobic. $\mathrm{NaCl}$ is required for growth. Positive for oxidase and catalase. The menaquinone is MK- 6 . The 
Table 1. Differential characteristics of strains $\mathrm{HN}-171^{\top}, \mathrm{HN}-172$ and $\mathrm{HN}-181$ and related genera

Taxa: 1, strains $\mathrm{HN}-171^{\mathrm{T}}$, HN-172 and HN-181; 2, Coenonia (Vandamme et al., 1999); 3, Gaetbulimicrobium (Yoon et al., 2006a); 4, Cellulophaga (Johansen et al., 1999; Bowman, 2000; Nedashkovskaya et al., 2004b); 5, Stanierella (Reichenbach, 1989; Nedashkovskaya et al., 2005b); 6, Winogradskyella (Nedashkovskaya et al., 2005a; Lau et al., 2005); 7, Psychroflexus (Bowman et al., 1998; Donachie et al., 2004). All are positive for alkaline phosphatase (not determined for Stanierella) and catalase activities. All are negative for urease activity and flexirubin pigments. Symbols: + , positive; -, negative; v, variable; $\mathrm{W}$, weakly positive; ND, not determined.

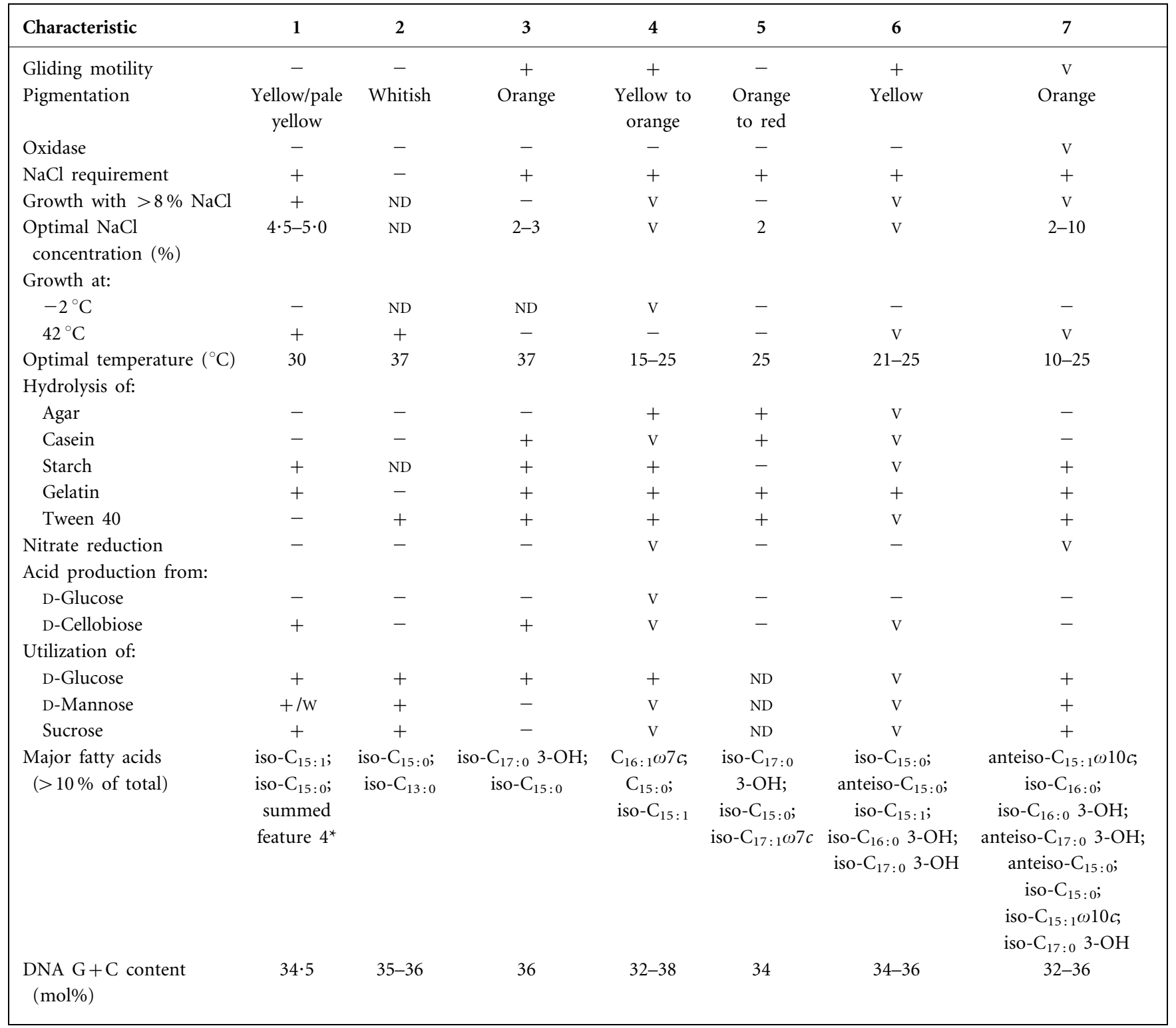

${ }^{\star}$ Summed feature 4 contains iso- $\mathrm{C}_{15: 0} 2-\mathrm{OH}$ and/or $\mathrm{C}_{16: 1} \omega 7 c / t$.

major fatty acids are iso- $\mathrm{C}_{15: 1}$, iso- $\mathrm{C}_{15: 0}$ and summed feature 4 . The type species is Zhouia amylolytica.

\section{Description of Zhouia amylolytica sp. nov.}

Zhouia amylolytica (a.my.lo.ly'ti.ca. Gr. n. amylos starch; N.L. adj. lyticus from Gr. adj. lutikos dissolving; N.L. fem. adj. amylolytica dissolving starch, pertaining to the ability of the bacterium to hydrolyse starch).
Exhibits the following properties in addition to those given in the genus description and in Table 1. Cells are $0 \cdot 25-0 \cdot 3 \times 1 \cdot 3-3 \cdot 0 \mu \mathrm{m}$ in size; devoid of flagellar and gliding motility. Colonies on MA are circular, slightly raised, smooth, yellow to pale-yellow in colour and $2 \cdot 0-3.0 \mathrm{~mm}$ in diameter after incubation for 2 days at $30{ }^{\circ} \mathrm{C}$. Growth occurs at $7-42^{\circ} \mathrm{C}$, with an optimum at $30^{\circ} \mathrm{C}$; growth does not occur at 4 or $45^{\circ} \mathrm{C}$. Growth is observed at $\mathrm{pH} 6 \cdot 0-8 \cdot 0$, with an optimum at $\mathrm{pH} 7 \cdot 2-7 \cdot 4$; growth does 
not occur at $\mathrm{pH} 5 \cdot 8$ or $8 \cdot 2$. Optimal growth occurs in the presence of $4 \cdot 5-5 \%(\mathrm{w} / \mathrm{v}) \mathrm{NaCl}$; growth does not occur in the absence of $\mathrm{NaCl}$ or in the presence of $>9 \%(\mathrm{w} / \mathrm{v}) \mathrm{NaCl}$. Nitrate is not reduced. Starch and gelatin are hydrolysed, but agar, casein and Tweens are not hydrolysed. Dextrin, $\alpha$-cyclodextrin, glycogen, $N$-acetyl-D-galactosamine, $N$ acetyl-D-glucosamine, D-cellobiose, D-fructose, L-fucose, D-galactose, gentiobiose, $\alpha$-D-lactose, maltose, D-melibiose, methyl $\beta$-D-glucoside, D-psicose, D-raffinose, L-rhamnose, D-sorbitol, D-trehalose, turanose, succinic acid monomethyl ester, acetic acid, D-galactonolactone, $\alpha$-ketobutyric acid, $\alpha$ ketoglutaric acid, $\alpha$-ketovaleric acid, DL-lactic acid, propionic acid, L-alanine, L-alanyl glycine, L-asparagine, L-aspartic acid, L-glutamic acid, glycyl L-aspartic acid, glycyl Lglutamic acid, L-leucine, L-ornithine, L-proline, L-threonine, urocanic acid, inosine, uridine, D-glucose 1-phosphate and D-glucose 6-phosphate are utilized. Tweens 40 and 80, adonitol, L-arabinose, D-arabitol, i-erythritol, myo-inositol, D-mannitol, xylitol, methyl pyruvate, cis-aconitic acid, citric acid, formic acid, D-galactonic acid, D-gluconic acid, Dglucosaminic acid, D-glucuronic acid, $\alpha$-hydroxybutyric acid, $\beta$-hydroxybutyric acid, $\gamma$-hydroxybutyric acid, itaconic acid, malonic acid, quinic acid, D-saccharic acid, sebacic acid, succinic acid, bromosuccinic acid, succinamic acid, glucuronamide, L-alaninamide, D-alanine, L-histidine, Lphenylalanine, L-pyroglutamic acid, D-serine, L-serine, DL-carnitine, $\gamma$-aminobutyric acid, thymidine, phenylethylamine, putrescine, 2-aminoethanol, 2,3-butanediol, glycerol and DL- $\alpha$-glycerol phosphate are not utilized. The major fatty acids are iso- $\mathrm{C}_{15: 1} \mathrm{G}(24 \cdot 2 \%)$, iso- $\mathrm{C}_{15: 0}(14 \cdot 9 \%)$, summed feature $4(10 \cdot 7 \%)$ and $\mathrm{C}_{15: 0}(9 \cdot 4 \%)$. The DNA $\mathrm{G}+\mathrm{C}$ content of the type strain is $34 \cdot 5 \mathrm{~mol} \%$.

The type strain, HN-171 ${ }^{\mathrm{T}}$ (=CGMCC $1.6114^{\mathrm{T}}=\mathrm{JCM}$ $\left.14016^{\mathrm{T}}\right)$, was isolated from a sediment sample from the South China Sea, China.

\section{Acknowledgements}

This work was supported by the National Natural Science Foundation of China (30230010). Our thanks go to Professor W.-Y. Zhuang at the Institute of Microbiology, Chinese Academy of Sciences, for her help with nomenclature.

\section{References}

Bernardet, J.-F., Segers, P., Vancanneyt, M., Berthe, F., Kersters, K. \& Vandamme, P. (1996). Cutting a Gordian knot: emended classification and description of the genus Flavobacterium, emended description of the family Flavobacteriaceae, and proposal of Flavobacterium hydatis nom. nov. (basonym, Cytophaga aquatilis Strohl and Tait 1978). Int J Syst Bacteriol 46, 128-148.

Bernardet, J.-F., Nakagawa, Y. \& Holmes, B. (2002). Proposed minimal standards for describing new taxa of the family Flavobacteriaceae and emended description of the family. Int J Syst Evol Microbiol 52, 1049-1070.

Bowman, J. P. (2000). Description of Cellulophaga algicola sp. nov., isolated from the surface of Antarctic algae, and reclassification of
Cytophaga uliginosa (ZoBell and Upham 1944) Reichenbach 1989 as Cellulophaga uliginosa com. nov. Int J Syst Evol Microbiol 50, 18611868.

Bowman, J. P. \& Nichols, D. S. (2002). Aequorivita gen. nov., a member of the family Flavobacteriaceae isolated from terrestrial and marine Antarctic habitats. Int J Syst Evol Microbiol 52, 1533-1541.

Bowman, J. P. \& Nichols, D. S. (2005). Novel members of the family Flavobacteriaceae from Antarctic maritime habitats including Subsaximicrobium wynnwilliamsii gen. nov., sp. nov., Subsaximicrobium saxinquilinus sp. nov., Subsaxibacter broadyi gen. nov., sp. nov., Lacinutrix copepodicola gen. nov., sp. nov., and novel species of the genera Bizionia, Gelidibacter and Gillisia. Int J Syst Evol Microbiol 55, 1471-1486.

Bowman, J. P., McCammon, S. A., Lewis, T., Skerratt, J. H., Brown, J. L., Nichols, D. S. \& McMeekin, T. A. (1998). Psychroflexus torquis gen. nov., sp. nov., a psychrophilic species from Antarctic sea ice, and reclassification of Flavobacterium gondwanense (Dobson et al. 1993) as Psychroflexus gondwanense gen. nov., comb. nov. Microbiology 144, 1601-1609.

Bruns, A., Rohde, M. \& Berthe-Corti, L. (2001). Muricauda ruestringensis gen. nov., sp. nov., a facultatively anaerobic, appendaged bacterium from German North Sea intertidal sediment. Int J Syst Evol Microbiol 51, 1997-2006.

Cho, J. C. \& Giovannoni, S. J. (2003). Croceibacter atlanticus gen. nov., sp. nov., a novel marine bacterium in the family Flavobacteriaceae. Syst Appl Microbiol 26, 76-83.

Cho, J.-C. \& Giovannoni, S. J. (2004). Robiginitalea biformata gen. nov., sp. nov., a novel marine bacterium in the family Flavobacteriaceae with a higher $\mathrm{G}+\mathrm{C}$ content. Int $J$ Syst Evol Microbiol 54, 1101-1106.

Collins, M. D. (1985). Isoprenoid quinone analysis in classification and identification. In Chemical Methods in Bacterial Systematics, pp. 267-287. Edited by M. Goodfellow \& D. E. Minnikin. London: Academic Press.

Donachie, S. P., Bowman, J. P. \& Alam, M. (2004). Psychroflexus tropicus sp. nov., an obligately halophilic Cytophaga-FlavobacteriumBacteroides group bacterium from an Hawaiian hypersaline lake. Int $J$ Syst Evol Microbiol 54, 935-940.

Dong, X.-Z. \& Cai, M.-Y. (2001). Determinative Manual for Routine Bacteriology. Beijing: Scientific Press.

Fitch, W. M. (1971). Toward defining the course of evolution: minimum changes for a specific tree topology. Syst Zool 20, 406-416.

Gerhardt, P., Murray, R. G. E., Wood, W. A. \& Krieg, N. R. (1994). Methods for General and Molecular Bacteriology. Washington, DC: American Society for Microbiology.

Hu, Y.-T., Zhou, P.-J., Zhou, Y.-G., Liu, Z.-H. \& Liu, S.-J. (2004). Saccharothrix xingjiangensis sp. nov., a pyrene-degrading actinomycete isolated from Tianchi Lake, Xinjiang, China. Int J Syst Evol Microbiol 54, 2091-2094.

Ivanova, E. P., Nedashkovskaya, O. I., Chun, J. \& 7 other authors (2001). Arenibacter gen. nov., new genus of the family Flavobacteriaceae and description of a new species, Arenibacter latericius sp. nov. Int J Syst Evol Microbiol 51, 1987-1995.

Johansen, J. E., Nielsen, P. \& Sjøholm, C. (1999). Description of Cellulophaga baltica gen. nov., sp. nov. and Cellulophaga fucicola gen. nov., sp. nov. and reclassification of [Cytophaga] lytica to Cellulophaga lytica gen. nov., comb. nov. Int J Syst Bacteriol 49, 1231-1240.

Jooste, P. J. (1985). The taxonomy and significance of FlavobacteriumCytophaga strains from dairy sources. $\mathrm{PhD}$ thesis, University of the Orange Free State, South Africa.

Jung, S. Y., Kang, S. J., Lee, M. H., Lee, S. Y., Oh, T. K. \& Yoon, J. H. (2005). Gaetbulibacter saemankumensis gen. nov., sp. nov., a novel 
member of the family Flavobacteriaceae isolated from a tidal flat sediment in Korea. Int J Syst Evol Microbiol 55, 1845-1849.

Lau, S. C., Tsoi, M. M., Li, X. \& 7 other authors (2005). Winogradskyella poriferorum sp. nov., a novel member of the family Flavobacteriaceae isolated from a sponge in the Bahamas. Int J Syst Evol Microbiol 55, 1589-1592.

Lau, S. C., Tsoi, M. M., Li, X., Plakhotnikova, I., Dobretsov, S., Wu, M., Wong, P. K., Pawlik, J. R. \& Qian, P. Y. (2006). Stenothermobacter spongiae gen. nov., sp. nov., a novel member of the family Flavobacteriaceae isolated from a marine sponge in the Bahamas, and emended description of Nonlabens tegetincola. Int J Syst Evol Microbiol 56, 181-185.

Mancuso, N. C., Bowman, J. P. \& Guezennec, J. (2005). Olleya marilimosa gen. nov., sp. nov., an exopolysaccharide-producing marine bacterium from the family Flavobacteriaceae, isolated from the Southern Ocean. Int J Syst Evol Microbiol 55, 1557-1561.

Marmur, J. \& Doty, P. (1962). Determination of the base composition of deoxyribonucleic acid from thermal denaturation temperature. J Mol Biol 5, 109-118.

Nedashkovskaya, O. I., Kim, S. B., Han, S. K. \& 7 other authors (2003). Mesonia algae gen. nov., sp. nov., a novel marine bacterium of the family Flavobacteriaceae isolated from the green alga Acrosiphonia sonderi (Kütz) Kornm. Int J Syst Evol Microbiol 53, 1967-1971.

Nedashkovskaya, O. I., Kim, S. B., Han, S. K., Rhee, M. S., Lysenko, A. M., Falsen, E., Frolova, G. M., Mikhailov, V. V. \& Bae, K. S. (2004a). Ulvibacter litoralis gen. nov., sp. nov., a novel member of the family Flavobacteriaceae isolated from the green alga Ulva fenestrata. Int J Syst Evol Microbiol 54, 119-123.

Nedashkovskaya, O. I., Suzuki, M., Lysenko, A. M., Snauwaert, C., Vancanneyt, M., Swings, J., Vysotskii, M. V. \& Mikhailov, V. V. (2004b). Cellulophaga pacifica sp. nov. Int J Syst Evol Microbiol 54, 609-613.

Nedashkovskaya, O. I., Kim, S. B., Han, S. K. \& 7 other authors (2004c). Maribacter gen. nov., a new member of the family Flavobacteriaceae, isolated from marine habitats, containing the species Maribacter sedimenticola sp. nov., Maribacter aquivivus sp. nov., Maribacter orientalis sp. nov. and Maribacter ulvicola sp. nov. Int J Syst Evol Microbiol 54, 1017-1023.

Nedashkovskaya, O. I., Kim, S. B., Han, S. K. \& 7 other authors (2004d). Algibacter lectus gen. nov., sp. nov., a novel member of the family Flavobacteriaceae isolated from green algae. Int J Syst Evol Microbiol 54, 1257-1261.

Nedashkovskaya, O. I., Kim, S. B., Han, S. K., Snauwaert, C., Vancanneyt, M. \& 7 other authors (2005a). Winogradskyella thalassocola gen. nov., sp. nov., Winogradskyella epiphytica sp. nov. and Winogradskyella eximia sp. nov., marine bacteria of the family Flavobacteriaceae. Int J Syst Evol Microbiol 55, 49-55.

Nedashkovskaya, O. I., Kim, S. B., Lysenko, A. M., Frolova, G. M., Mikhailov, V. V., Lee, K. H. \& Bae, K. S. (2005b). Description of
Aquimarina muelleri gen. nov., sp. nov., and proposal of the reclassification of [Cytophaga] latercula Lewin 1969 as Stanierella latercula gen. nov., comb. nov. Int J Syst Evol Microbiol 55, 225-229.

Nedashkovskaya, O. I., Kim, S. B., Lysenko, A. M., Frolova, G. M., Mikhailov, V. V. \& Bae, K. S. (2005c). Bizionia paragorgiae gen. nov., sp. nov., a novel member of the family Flavobacteriaceae isolated from the soft coral Paragorgia arborea. Int J Syst Evol Microbiol 55, 375-378.

Nedashkovskaya, O. I., Kim, S. B., Lysenko, A. M., Frolova, G. M., Mikhailov, V. V., Bae, K. S., Lee, D. H. \& Kim, I. S. (2005d). Gramella echinicola gen. nov., sp. nov., a novel halophilic bacterium of the family Flavobacteriaceae isolated from the sea urchin Strongylocentrotus intermedius. Int J Syst Evol Microbiol 55, 391-394.

Reichenbach, H. (1989). Genus Cytophaga Winogradsky 1929, 577, ${ }^{\mathrm{AL}}$ emend. In Bergey's Manual of Systematic Bacteriology, vol. 3, pp. 2015-2050. Edited by J. T. Staley, M. P. Bryant, N. Pfennig \& J. C. Holt. Baltimore: Williams \& Wilkins.

Saitou, N. \& Nei, M. (1987). The neighbor-joining method: a new method for constructing phylogenetic trees. Mol Biol Evol 4, 406425.

Thompson, J. D., Gibson, T. J., Plewniak, F., Jeanmougin, F. \& Higgins, D. G. (1997). The CLUSTAL_X windows interface: flexible strategies for multiple sequence alignment aided by quality analysis tools. Nucleic Acids Res 25, 4876-4882.

Vandamme, P., Vancanneyt, M., Segers, P., Ryll, M., Köhler, B., Ludwig, W. \& Hinz, H.-H. (1999). Coenonia anatina gen. nov., sp. nov., a novel bacterium associated with respiratory disease in ducks and geese. Int J Syst Bacteriol 49, 867-874.

Van de Peer, Y. \& De Wachter, R. (1994). TREECON for Windows: a software package for the construction and drawing of evolutionary trees for the Microsoft Windows environment. Comput Appl Biosci 10, 569-570.

Wu, C., Lu, X., Qin, M., Wang, Y. \& Ruan, J. (1989). Analysis of menaquinone compound in microbial cells by HPLC. Microbiology [English translation of Microbiology (Beijing)] 16, 176-178.

Yoon, J. H., Kang, S. J., Lee, C. H. \& Oh, T. K. (2005). Dokdonia donghaensis gen. nov., sp. nov., isolated from sea water. Int $J$ Syst Evol Microbiol 55, 2323-2328.

Yoon, J.-H., Kang, S.-J., Jung, S.-Y., Oh, H. W. \& Oh, T.-K. (2006a). Gaetbulimicrobium brevivitae gen. nov., sp. nov., a novel member of the family Flavobacteriaceae isolated from a tidal flat of the Yellow Sea in Korea. Int J Syst Evol Microbiol 56, 115-119.

Yoon, J. H., Kang, S. J., Lee, C. H. \& Oh, T. K. (2006b). Donghaeana dokdonensis gen. nov., sp. nov., isolated from sea water. Int J Syst Evol Microbiol 56, 187-191.

Zhang, D., Yang, H., Zhang, W., Huang, Z. \& Liu, S.-J. (2003). Rhodocista pekingensis sp. nov., a cyst-forming phototrophic bacterium from a municipal wastewater treatment plant. Int J Syst Evol Microbiol 53, 1111-1114. 